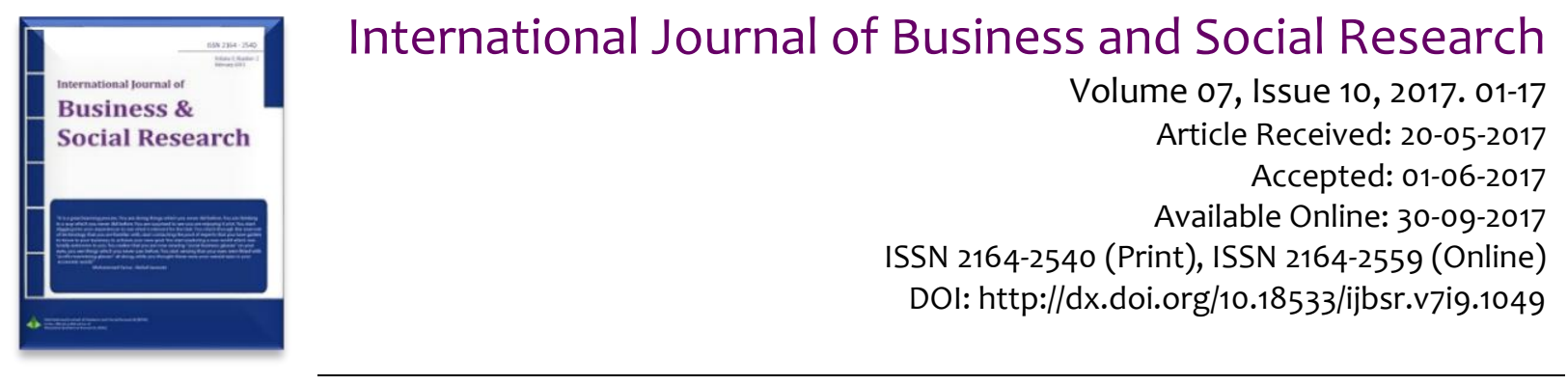

\title{
Conflict between Supermarkets and Wet-Markets in Ghana: Early Warning Signals and Preventive Policy Recommendations
}

\author{
Etornam Kosi Anku1, Gerald Kojo Ahorbo²
}

\begin{abstract}
The source of conflict between Supermarkets and Wet-markets arise from the use of market power and economies of scale by one group against the other. This study explores the tensions that exist between modern retailers and their traditional counterparts as a result of the influx of supermarkets in Ghana. The main objective of the study is to compare attributes related to the control of access to consumers by the Supermarket and the Wet-market. In this study, the dot-survey approach of Rapid Market Assessment Technique was used to elicit information from 438 respondents at the Madina market (wet-market) and Melcom (supermarket) over a period of two weeks and Wilcoxon-MannWhitney (WMW) comparison test and descriptive statistics were employed for the analysis. The results revealed that consumers patronise the supermarkets for convenience and the wet-market for freshness of product. Their purchasing decisions were affected by their level of education and product selections of the retailer. The highly educated preferred to shop at the Supermarket instead of the Wet-market; however, over $50 \%$ of respondents preferred the wet-market for fresh food products and the supermarket for non-food items. Each retailer receives its fair share of purchases from its loyal customers, therefore the revolution arising from the supermarket influx in Ghana has not yet resulted into conflict between supermarkets and their traditional counterparts, though it is inevitable if nothing is done to prevent it from happening. To avoid the conflict, it is recommended that policies should be instituted to (i) improve the market infrastructures and shopping environment in the Wet-markets, (ii) give tax concession to modern retailers who source products from local farmers and small-scale processors, (iii) enable traditional retailers position themselves on the fringe and co-exist with modern retailers and (iv) enforce public standards with regards to food safety laws in the traditional markets.
\end{abstract}

Keywords: Ghana, Market tensions, Supermarkets, Wet-markets, Wilcoxon-Mann-Whitney test.

JEL Codes: C12, D43, L11, L13, L81.

This is an open access article under Creative Commons Attribution 4.0 License, 2017.

\footnotetext{
${ }^{1}$ Lecturer, Department of Agro Enterprise Development, Faculty of Applied Sciences and Technology, Ho Technical University. Email: eanku@htu.edu.gh

${ }^{2}$ Lecturer, Department of Agro Enterprise Development, Faculty of Applied Sciences and Technology, Ho Technical University. Email: gahorbo@htu.edu.gh
} 


\section{Introduction}

The entrance and long existence of supermarkets ${ }^{3}$ in retail sectors of developed and developing economies create conflicts with their traditional counterparts because supermarkets entice their customers from the traditional retailers. Academic literature demonstrates that there exist several studies that tried to identify the sources of these conflicts (Reardon, 2011), however, there is still very little empirical study that evaluates the impact of the operations of the supermarkets on traditional retailers in developing countries (Suryadarma, 2011). For instance, Reardon and Hopkins (2006) indicated that tensions between supermarkets and traditional retailers ${ }^{4}$ are caused by the supermarket's pricing strategy, quality and safety of products sold, and convenience in service delivery which leads to "price war", "quality war" and "convenience war". They also found that these conflicts usually occur after a decade of the supermarket revolution, and the intensity of the conflict is low when the supermarket's share of the retail market is small as compared to the traditional retail market (Reardon and Hopkins, 2006). Other studies also reveal that the source of conflicts between these retailers usually emanate from the use of market power (Reardon and Gulati, 2008b) and economies of scale (Reardon et al., 2010). Notwithstanding these conflicts and tensions, several studies also demonstrate that traditional retailers are building strong resilience against the supermarkets especially in the niche market of fresh food products and in low-income consumer segments (Coe and Wrigley, 2007; Humphrey 2007).

In spite of the large volume of academic literature on the activities of supermarkets (including modern retail formats), there are still very scanty empirical studies documented on the implications of modern retail on the fortunes of traditional retailers in Africa, West-Africa and in Ghana for that matter. This trend was also noted by Weatherspoon and Reardon (2003) in which they reported the following as the reasons for the low documented research on supermarkets in Africa:

"(i)...the development of supermarket diffusion in Africa has been rapid and very recent.

(ii) The traditional image of supermarkets in all the development literature is one of a luxury niche, quite irrelevant to development and the poor, a mere curiosity for specialists.

(iii) Most market research in Africa has focused on wholesale markets for grain

(iv) Where 'supermarkets' have been targeted by recent Africa research, they have mainly been UK supermarkets procuring horticultural products and fish from Kenyan and South African growers"

(Weatherspoon and Reardon, 2003, p.334)

In recent years, majority of the studies on modern retailers in Africa have concentrated on Southern Africa (e.g. Battersby and Peyton, 2014; Peyton et al., 2015; Crush and Frayne, 2011; D'Haese and van Huylenbroek, 2005; Minten et al., 2005), and East Africa (e.g. Assefa et al., 2016; Andersson et al., 2015; Quaim et al., 2014; Rao and Quaim, 2011; Neven et al., 2009; Neven et al., 2006; Neven and Reardon, 2004; Weatherspoon and Reardon, 2003), with little research activity on North Africa (e.g. Tessier et al., 2010), West Africa and Ghana (e.g. Duedu et al., 2014; Meng et al., 2014a; Meng et al., 2014b; Mabogunje, 1964).

The retail sector in Ghana has undergone tremendous diversification in the past three decades since Melcom, the household name for supermarkets [in Ghana], started operations in the country in the early $1990 \mathrm{~s}$. Melcom is the only modern retail shop in the country with the most widespread chain of stores, though some new entrants like Shoprite are also expanding fast in recent years. Melcom started its operation around the same time that other developing countries were experiencing the first-wave of the supermarket revolution by Multi-national retail chains (Melcom Group, 2010a; Reardon and Gulati, 2008a; Reardon et al., 2007). Since then, not much has been seen of Supermarkets until the 2000s. By the early 2000s, the influx of Foreign Direct Investment (FDI) into the Ghanaian economy increased by 117 percent (from 1999 to about 2004) while GDP grew by 14.1 percent (World Bank Group, 2007; UNCTAD, 2003). The increase in FDI spurred activities of modern retailers (Reardon et al., 2010) including Max-mart, Koala and Woolworths (an affiliate of Marks \& Spencer from South Africa). These economic events coupled with the development of retail infrastructure in the country (like the A\&C shopping Mall,

\footnotetext{
3 For this research, supermarket shall refer to '... all modern retail, which include chain stores of various formats such as supermarkets, hypermarkets, and convenience and neighbourhood stores' as used by Reardon and Gulati (2008a, p.1).

4 In this paper, traditional retailers refer to the group of small-scale farmers, producers, processors and retailers. They include operators of table-top shops, kiosks, provision shops, wet-markets, open markets, community markets, farmers markets and general trading shops.
} 
Accra Mall, Marina Mall, Legon Mall, The Junction Mall, Achimota retail centre and the West Hills Mall among others) attracted Multi-national retailers including Shoprite, Game, mrp, and Marina Supermarket, as well as other local discount stores like Orca Deco and Palace hypermarket. These events placed Ghana in a good position to be part of the on-going fourth-wave supermarket revolution (Reardon et al., 2003). Since supermarkets are late entrants in the retail sector of the Ghanaian market, it is likely they lured consumers from the traditional retailers which is expected to create conflict that could lead to closure of their businesses as happened elsewhere such as in Chile (Faiguenbaum et al., 2002).

\subsection{Statement of the problem}

The diffusion of modern supermarkets in developing economies (and to some extent, the developed ones), has detrimental implications on the fortunes of traditional retailers. The exclusion of small-scale farmers, processors and retailers from the supermarket supply chain, the use of value pricing, the control of access to consumers, technology, land and labour by supermarkets, are likely detrimental implications to be experienced in the retail sector of Ghana as the share of Supermarkets continue to rise (Timmer, 2004). This rise in the supermarket's share of the retail market results in a consequential decline in the share of traditional retail shops as experienced in Chile (Faiguenbaum et al., 2002) and Argentina (Rodriguez et al., 2002). This decline is attributed to the differential capabilities of the traditional retailers to resist the strong competition posed by the modern retailers (Coe and Wrigley, 2007). The policy dilemma that confronts policy makers is how to compensate and reposition traditional retailers in the face of strong competition from supermarket retail giants to ensure the symbiotic co-existence of both retailers.

\subsection{Objective of the study}

The objective of this study is to compare attributes related to the control of access to consumers by the Madina market and Melcom supermarket and also explore the tensions that exist between modern retailers and their traditional counterparts in Ghana.

\subsection{Contribution of the study}

This study will ultimately provide the Municipal Authorities in-charge of traditional markets and policy makers with information that will help create enabling environment for healthy competition and peaceful co-existence of the traditional retailers (mostly in the wet-markets) and the modern retailers (mostly the supermarkets).

\subsection{Structure of the paper}

The rest of the paper is presented in six (6) main sections. Section 2 presents the literature review and discusses related topics as super market revolution and associated conflicts; relationship between Melcom supermarket and the traditional retailers; Implications of the supermarket revolution on traditional retailers; and the hypotheses development. Section 3 discusses the methodology adopted for the study. The data collection procedure, the research design, the use of the Wilcoxon-Mann-Whitney test analysis conducted and descriptive statistical outputs are all presented in this section. Sections 4 and 5 present the results and discussions of the various findings within the context of extant literature. Section 6 presents the conclusion arrived at and Section 7 talks about the policy implications of the study necessary for policy makers to take action to avert any conflict from erupting.

\section{LITERATURE REVIEW}

\subsection{Supermarket revolution and associated conflict with traditional markets}

Supermarkets are modern discount (organised) retail formats including Supercentres and Hypermarkets backed by Trans-national corporations (TNCs) and Multi-national corporations (MNCs) with high market power (Timmer, 2004). They employ procurement systems modernisation, and economies of scale and scope to reduce operational cost to sell their produce cheaper to their valued customers (Reardon et al., 2003). The rapid spread of supermarkets in developing countries began from early to mid-1990s and emerged in different stages called "Waves" (Reardon et al., 2005) (see table 1). 
This diffusion is well documented by Minten (2008), Reardon and Gulati (2008b), Readon and Hopkins (2006), Hu et al. (2004), Reardon et al. (2003) among others. The emergence of supermarkets presents both opportunities and challenges to traditional retailers in various jurisdictions where supermarkets operate. The advent of the supermarket revolution came with rivalled tensions between the supermarkets and their traditional retail counterparts with for instance several protests by traditional retailers in India (BBC News India, 2012; Reuters, 2011; Neven et al., 2006).

Table 1: The Three waves of supermarket revolution in developing countries

\begin{tabular}{|c|c|c|}
\hline Period & Countries/regions & $\begin{array}{l}\text { Growth in supermarkets' average share } \\
\text { in retail sales }\end{array}$ \\
\hline $\begin{array}{l}\text { First wave started in } \\
\text { early } 1990 \text { s }\end{array}$ & $\begin{array}{l}\text { Much of South America, East Asia } \\
\text { (outside China), and South Africa }\end{array}$ & $\begin{array}{l}\text { From } 10 \text { percent around } 1990 \text { to about } \\
50-60 \text { percent by the mid-2000s }\end{array}$ \\
\hline $\begin{array}{l}\text { Second wave started } \\
\text { in mid- to late } 1990 \text { s }\end{array}$ & $\begin{array}{l}\text { Mexico, Central America, and much } \\
\text { of Southeast Asia }\end{array}$ & $\begin{array}{l}\text { From } 5-10 \text { percent in } 1990 \text { to } 30-50 \\
\text { percent by the mid-2000s }\end{array}$ \\
\hline $\begin{array}{l}\text { Third wave started in } \\
\text { late 1990s and early } \\
\text { 2000's }\end{array}$ & China, India and Vietnam & $\begin{array}{l}\text { Reached about } 2-20 \text { percent by mid- } \\
\text { 2000s; supermarket sales grew at 30-50 } \\
\text { percent a year }\end{array}$ \\
\hline
\end{tabular}

Source: Adapted from Reardon and Gulati (2008a, p.1)

Reardon et al. (2005) demostrate how the opportunity given to small firms in the Pacific Rim to enter the supermarket supply chain yielded gains in trade development, in that, they are able to move from being local suppliers to become national, regional and global suppliers of supermarkets, thereby increasing profits. Another example is seen in Madagascar where about ten thousand farmers were given the opportunity to supply to supermarkets in Europe by giving them technical support to meet quality standards of supermarkets (Minten et al., 2005). On the other hand, the challenges presented to those who could not afford the costs involved in changing production practices to meet supermarket standards and volume requirements include being excluded from the supply chain and are also driven out of business (Reardon et al., 2005; Faiguenbaum et al., 2002; Rodriguez et al., 2002). Markedly noted by Reardon and Gulati (2008a):

The supermarket revolution is a "two-edged sword." On the one hand, it can lower food prices for consumers and create opportunities for farmers and processors to gain access to qualitydifferentiated food markets and raise incomes. On the other hand, it can create challenges for small retailers, farmers, and processors who are not equipped to meet the new competition and requirements from supermarkets' (Reardon and Gulati, 2008a, p.1).

These challenges present a source of conflict between the supermarkets and traditional retailers which usually emanate from the use of market power and economies of scale by one group of retailers against another group. Rightly posited by Reardon and Gulati (2008b):

"The two basic sources of conflict between the supermarkets on one side and the traditional retailers... on the other are (1) inequality of power based on supermarkets' greater concentration and scale and greater access to technologies and commercial practices because of that scale; and (2) the practices and strategies through which supermarkets wield their power, magnifying their initial advantages through pricing, quality, location, payment, and contracting" (Reardon and Gulati, 2008b, p.23).

The use of this unequal power enables supermarkets to attract a greater portion of customers from the traditional retailers, thereby driving traditional retailers out of business as evidenced in Chile, where between 1991 and 1995, 21\% of general food shops, 21\% of beverages and liquor shops, $22 \%$ of fresh meat shops, $25 \%$ of cold cuts and roast meat shops, $22 \%$ of fish shops, $25 \%$ of milk and dairy shops and $17 \%$ of fruits and vegetable shops went out of business due to the presence of supermarkets (Faiguenbaum et al., 2002). Natawidjaja et al. (2006) in Reardon and Hopkins, 2006) also noted that while supermarkets sales increased by $15 \%$ a year, traditional retail sales consequentially declined by $2 \%$ a year.

Where supermarkets and traditional retailers serve the same consumer segments, there is tendency for tension to erupt with costs that have social, political and economic dimensions (Reardon 
and Hopkins, 2006). However, if they complement each other or if supermarkets have a smaller share of the retail market, then the tension is low and inconsequential (Suryadarma, 2011; Readon and Hopkins, 2006). In fact there are studies which demonstrate that traditional retailers out-compete the supermarkets (Goldman and Hino, 2005; Suryadarma, 2011), whereas others built strong resilience to the competition posed by Modern retail (Hamilton, 2003) even though in most of the conflict situations, traditional retailers have been on the losing side to supermarkets. Conflict situations within the retail sector have been tackled by way of regulation and policy oriented approaches, while others have been by command-and-control. For example, Reardon and Hopkins (2006) report that the Military government in Thailand threatened larger foreign-owned retailers with prison terms of up to zyears or fines of up to USD 156, 193 in an attempt to hold back expansion plans of supermarkets and protect smaller stores. Coe and Wrigley (2007) also report that some governments are instituting regulations to enforce public standards in order to increase consumer confidence in food safety in the traditional market (e.g "Green Food labelling" in China reported by Humphrey 2007) while others are matching modern retail private standards in the traditional retail sector (e.g. "Safe vegetable cooperatives" in Vietnam as reported by van Wijk et al., 2005)

\subsection{Relationship between melcom supermarket and the traditional retailers}

The Madina market (the case in study) is representative of the monopolistic fringe ${ }^{5}$ within the market structure (Figure 1). It comprises of many small sellers who are into the sale of food items, electronics, hardware, clothes etc. In order to remain competitive in the market place, these traders have specific customers (niche) that patronize their goods and services. The Madina market is a wet market and it is close to major institutions such as Banks, Hospitals, and Police station. The very high population density in the La-Nkwantanang-Madina Municipality, has caused an unprecedented upsurge in the number of buyers and sellers in the Madina market, to the extent that the spill-over market is as far as $500 m$ away from the main market unto the main Legon-Madina-Adenta road (Lomotey, 2013; Ministry of Local Government \& Rural Development, 2013; MOFA, 2013). Melcom supermarket was established in 1989 and started operation in 1991 with the opening of its first shop in Accra central (Melcom Group, 2010a). It is the largest discount store with retail chain in 26 locations across the country (Melcom Group, $2010 \mathrm{~b}$ ). The Madina branch is one of the latest and largest group-of-four called the MelcomPlus that touts to offer over 40,000 items under one roof, bringing convenience and one-stop-shopping experience to its customers (Melcom Group, 2010a).

The market structure of the retail sector in Ghana is largely monopolistically competitive. However, the relationship between Melcom and the other traditional retailers is like that of a dominant oligopoly with a monopolistically competitive fringe (Figure 1). Part I of Figure 1 illustrates the firm diagram for the dominant firm (Melcom), while Part II illustrates the market structure for the retail sector in the country. QD represents the market demand for retail products sold by supermarkets and wetmarkets. Melcom's share of the market demand is illustrated by $A B=Q_{D}-Q_{s}$, leaving $0 Q_{s}$ for the fringe to share (Part II of Figure 1). The dominant firm is able to capture this large market share due to its cost advantages in meeting the demands of consumers together with its lower price $\left(\mathrm{P}^{*}\right)$ instead of the market price $(P)$.

Wet-markets have always existed to serve consumers in their localities and a few first time visitors (Minten et al., 2010; Timmer, 2004). Traditionally, food was the main item sold in wet-markets (Minten et al., 2010); however, with rapid urbanisation of rural communities in developing countries, Wetmarkets now trade, not only in food, but also in assorted products ranging from electrical and electronic to gardening equipment. Retailers in wet-markets fall within the perfectly competitive market structure with each seller dealing in homogeneous products and are unable to compete on price. Each vendor therefore has a niche of loyal customers to whom they sell their products. Within the last decade, the entry (into the Ghanaian market) of Woolworths, Orca Deco, Palace hypermarket, and most recently Shoprite, Game, mrp, Marina supermarket and "Shop n Save" is giving the management of Melcom a

\footnotetext{
$5 \mathrm{~A}$ monopolistically competitive fringe is a group of sellers in the same market as the dominant player but do not have the market power to engage in price competition. They either take the price set by the dominant player or risk losing their customers. The players in the fringe are only able to survive in the market by product differentiation and also carving a niche for themselves.
} 
more rigorous competition for market power. That notwithstanding, Melcom is still the leader in the retail market with the largest chain and bringing convenience shopping to the doorstep of all consumers in both "rich" and "poor" regions of the country. Melcom uses television advertising, the World Wide Web (www) and social media such as Facebook and Youtube to advertise and brand its name and products, thereby cutting down on cost to enable it sell cheaper products to its customers. It is therefore not surprising to find Melcom synonymous to slogans such as "The Cedi Saver", "Your One-Stop Shop", "The House of Bargains", "Where Quality Costs Less", and "Where Ghana Shops" (Melcom Group, 2010c).

Figure 1: Dominant oligopoly with a monopolistically competitive fringe

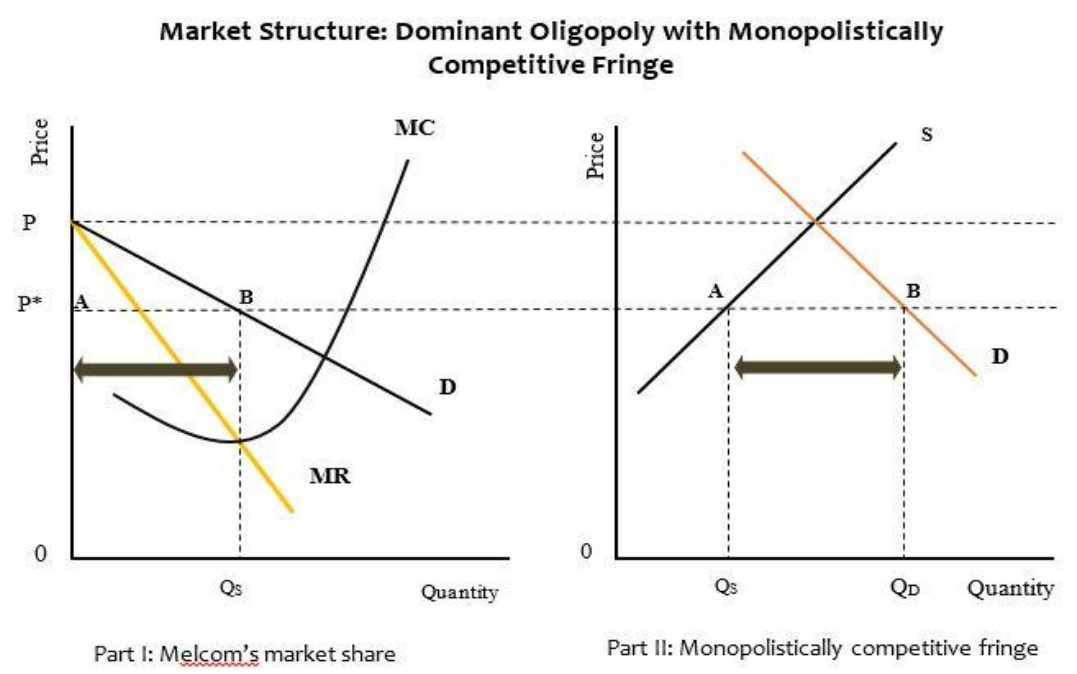

Source: Adapted from McTaggart, Findlay \& Parkin (2010, P361). P = Equilibrium market price. $\mathrm{P}^{*}=$ price set by Melcom. $A B=$ Melcom's share of Market. $\mathrm{OA}=$ Market share of the fringe.

\subsection{Implications of the supermarket revolution on traditional retailers}

Traditional markets have existed well and long before the advent of the supermarkets in developing countries as well as the very developed regions like the United States of America and Europe (Reardon et al., 2005; Mabogunje 1964). With the rapid rise of supermarkets as late entrants into the retail market, they have developed their customer base by attracting consumers from the traditional retailers. Supermarkets have consistently been accused of selling at unfairly low prices (e.g. D'Haese and van Huylenbroek, 2005; Neven et al., 2006; Reardon and Hopkins, 2006). Lower prices (in food and nonfood products) have been argued to bring relief to lower and middle-income consumers whose cost of consumption basket would be reduced drastically, however, a mirror-effect is the closure of traditional retail businesses as experienced (leading to tensions) in Chile, Argentina and India among others (Reardon and Hopkins, 2006; Faiguenbaum et al., 2002; Rodriguez et al., 2002). However, a symbiotic coexistence of the two retail formats would require that traditional retailers source their products from the modern retailers as their wholesalers (Biles et al., 2007; Bile, 2006; May, 2006 in Coe and Wrigley, 2007) or vice-versa in the case of Vietnam (van Wijk et al., 2005). It is further argued that in instances where the traditional retailers and modern supermarkets are seen to complement each other, the incidence of tension is non-existent. In these cases supermarkets sell to middle and upper class consumers (selling processed food and non-food items) while the traditional retailers sell to low-income consumers (fresh food products) (Suryadarma, 2011; Coe and Wrigley, 2007). Where small-scale farmers and processors are privileged to supply to supermarkets, the case of conflict is also non-existent. Example is the case of Madagascar as reported by Minten et al. (2005), where about 10,000 farmers were given "microcontracts" to supply to supermarkets in the UK. The benefits that this opportunity bring to the farmers include improved access to inputs, credit, extension services, technology adoption and productivity spillover effects on other crops (Minten et al., 2005).

A number of studies in the past have outlined the strategies used by supermarkets in their quest to build and increase their market share (e.g. Timmer, 2004; Timmer, 2009; Reardon et al., 2004; Reardon 
et al., 2005; Suryadarma, 2011; Minten et al., 2010; Neven et al., 2006) some of which are survey based and others anecdotal cases. A classic example central to this current study is the one presented by Goldman and Hino (2005) which is corroborated in a later study by Minten et al. (2010) and an earlier study by Hu et al. (2004). The first strategy is geographic segmentation: It is seen that in the early stages of the supermarket revolution, supermarkets open in urban cities where they can access the rich and affluent consumers, and later move to peri-urban and rural areas [which Weatherspoon and Reardon (2003) refer to as "supermarket for the poor"] (e.g. Slater and Henley, 1969 in Goldman and Hino, 2005; Coe and Wrigley 2007). They do this to reach out to all consumer segments with a large merchandise variety and compete with traditional retailers for their customers. The second strategy is profile of consumers: The academic literature also found that higher-income earners are more likely to shop at modern supermarkets as a result of their concern for quality, variety, safety, and the opportunity cost of their time involved in doing several stop-overs to buy from small shops compared to a one-stop-shopping in supermarkets among others (Minten et al., 2010; Reardon et al., 2010; Hu et al., 2004). Research has also shown that there is a correlation between consumer's income, education, concern for food safety and where a consumer shops (Hu et al, 2004). The third strategy is product offerings: Supermarkets attract consumers by selling quality products at lower prices (value pricing). In the early days of supermarket diffusion, supermarkets had competitive advantage over their traditional counterparts only in processed food and non-food products.

Over time, supermarkets are able to gain competitive advantage also in staples and fresh food products, selling cheaper than traditional retailers (Minten et al., 2010; Reardon et al., 2010; Hu et al., 2004)

\subsection{Hypothesis development}

Extant studies on supermarkets and traditional retailers used different empirical approaches. Meng et al. (2014b) used the Multivariate ordered probit model to predict the probability of a consumer to patronise food items from the supermarket, hawkers or open-air markets in urban Ghana. Suryardama (2011) used the difference-in-difference technique as well as the fixed effects estimation method to compare the performance of traditional retailers before and after the supermarket revolution in Indonesia in order to evaluate the effect of supermarkets on traditional retail.

Goldman and Hino (2005) used the binomial logit model to estimate the probability of a respondent to shop either at the supermarket or the traditional retail store among Israeli Arabs. Rodrigueze et al. (2002) also used the probit model to estimate the determinants of a household's choice of food retailer (super/hypermarket or small market) given certain indicators of socio-economic strata in Argentina. Most of the scholarly materials found, and as also observed by Suryadarma (2011), did not use any empirical approach to evaluate the impact of modern retail on traditional retail stores, instead, they used anecdotal studies of case-study approach to outline the implications of supermarkets on traditional retailers.

The studies of Meng et al. (2014b), Goldman and Hino (2005) and Rodrigueze et al. (2002) were concerned about a consumer's choice of food retailer. Suryadarma (2011) considered the effect of modern retail on traditional retail (as is our current study), however, they used the vendors as the respondents instead of consumers in our case.

In this study, the approach of profiling consumers to predict the incidence of conflict between modern retailers and traditional retailers was supported by the work of Timmer (2004) which posits that the control of access to consumers poses a major source of conflict between the two retail formats. Using the Wilcoxon-Mann-Whitney (WMW) comparison test, the associated research hypothesis that "there is a significant difference in the shopping behaviours of respondents at the supermarket and those at the traditional market" was then formulated.

The hypothesis for the WMW is:

$\mathrm{H}_{\mathrm{o}}$ : distribution of group $\mathrm{y}_{\mathrm{mp}}=$ distribution of group $\mathrm{y}_{\mathrm{mm}}$

Where $\quad y_{\mathrm{mp}}=$ respondents at Melcom supermarket

$\mathrm{y}_{\mathrm{mm}}=$ respondents at the Madina market

In formulating the above hypothesis, the following research questions were posited:

a. Do modern retailers scramble for the same consumer segment as wet-markets? 
b. To what extent does price, product quality and convenience in service delivery affect consumer choice of retail format in Ghana?

c. What are the implications of the penetration of supermarkets in Ghana on traditional retailers with respect to the types of products sold?

\section{METHODOLOGY}

The study was carried out at two retail centres Madina market (wet-market) and Melcom plus (supermarket) in Madina, the capital of the La-Nkwantanang-Madina Municipal Assembly in the Ga East of the Greater Accra region of Ghana with a population density of 1,564 persons per square kilometre. The gender stratification in the area is 51 percent females and 49 percent males, with an adult population (made up of persons aged 18 and above) of 64 percent (Ghana Statistical Service, 2012). There are about 66,286 households in the municipality with about 4 persons per household (Ghana Statistical Service, 2012). Ga East is largely urban with 87.5 percent of the municipality's population residing on 35 percent of the total land area which is urban and the remaining 12.5 percent living on 65 percent of total land area which is rural agricultural (Ghana Statistical Service, 2012; MOFA, 2013). The study area was purposively selected on the basis of the location of a modern supermarket and the closest wet-market. The population for the study is made up of consumers in the La-Nkwantanang-Madina Municipality and the respondents were sampled from patrons at the retail centers at the specific dates on which the study was carried out. A total of about 438 respondents were sampled from the two retail centers over two weeks.

The Dot-survey technique, a form of consumer intercept survey, adopted from the Rapid Market Assessment Tool, was used to elicit information necessary for the study (Lev et al., 2008). The dot-survey is used mainly in the United States to sample shoppers' perception and experience of Farmers' markets (Ragland et al., 2011; Hawthorne Valley Farm, 2010). According to Larry Lev (the designer), the dot method is interactive, intriguing and entertaining and creates excitement in both the researcher and the respondents when collecting and analyzing data (Lev et al., 2007).

The survey was conducted on Saturday, Wednesday and Friday. The significance of the days on which the samples were taken includes the fact that Saturdays and Wednesdays are the traditional market days for Madina market where both sellers and buyers within and outside the Madina Municipality are drawn in for trading activities. Friday happens to be the end of the week, and buyers who may be busy at social gatherings on Saturday may want to do their shopping on this day. The survey was conducted in two stages. The first stage involved eight (8) closed ended questions written on giant sheets of paper and displayed on easels in very populated locations in the market to attract interested patrons. Consumers indicate their choice of answer by placing orange coloured sticker dots (for males) or green coloured sticker dots (for females) on the poster. The second stage involved six (6) closed ended questions about customer profile and demographics, type-written on a one page A4 sheet. The questions were asked quickly and within 10 minutes the entire survey is completed. None of the respondents who participated in the survey at the Madina market were at Melcom during the times the survey was conducted at Melcom. At the end of the three days, all the data were pooled together for each retailer. The data obtained from the Madina market and Melcom supermarket were combined and analysed. STATA statistical software version 13.1 was used to process the data obtained from both shopping centres. The analysis employed the use of descriptive statistics (frequency tables and histograms) and the WMW comparison test. The WMW test was used to compare the distribution of respondents' attributes of education, income, age, gender, residence, and the retailers' attributes of pricing, quality, variety, clean environment, proximity, customer service, one-stop-shopping and types of products sold to determine how they differ in their choices.

\section{RESULTS}

4.1 The demographic information comparing the customer profiles are shown in table 2

Table 2: Demographic information

Retail Centre 


\begin{tabular}{|c|c|c|c|}
\hline & & & \multirow{2}{*}{ Melcom supermarket } \\
\hline \multicolumn{2}{|l|}{ Variables } & Madina market & \\
\hline \multicolumn{4}{|l|}{ Sex } \\
\hline & Male & $18.7 \%$ & $35.3 \%$ \\
\hline & Female & $81.3 \%$ & $64.7 \%$ \\
\hline & Total & $100 \%$ & $100 \%$ \\
\hline \multicolumn{4}{|c|}{ Residence } \\
\hline & Accra & $92 \%$ & $94.2 \%$ \\
\hline & Tema & $3.8 \%$ & $4.5 \%$ \\
\hline & Other regions & $4.2 \%$ & $1.3 \%$ \\
\hline & Total & $100 \%$ & $100 \%$ \\
\hline \multicolumn{4}{|c|}{ Age group } \\
\hline & $15-25$ & $20.7 \%$ & $34.4 \%$ \\
\hline & $25-45$ & $62 \%$ & $50 \%$ \\
\hline & $45-55$ & $11.7 \%$ & $13.4 \%$ \\
\hline & Above 55 & $5.6 \%$ & $2.2 \%$ \\
\hline & Total & $100 \%$ & $100 \%$ \\
\hline \multicolumn{4}{|c|}{ Means of Transport } \\
\hline & Walked & $9.4 \%$ & $15.1 \%$ \\
\hline & Motorbike/Bicycle & $3.3 \%$ & $4 \%$ \\
\hline & Taxi & $24 . .4 \%$ & $19.6 \%$ \\
\hline & Commercial Bus (Trotro) & $36.6 \%$ & $20.4 \%$ \\
\hline & Private car & $26.3 \%$ & $40.9 \%$ \\
\hline & Total & $100 \%$ & $100 \%$ \\
\hline \multicolumn{4}{|c|}{ Education level } \\
\hline & Tertiary education & $37.6 \%$ & $51.6 \%$ \\
\hline & Secondary education & $47.9 \%$ & $38.2 \%$ \\
\hline & Basic Education (JHS) & $8.5 \%$ & $6.2 \%$ \\
\hline & Primary School & $6 \%$ & $4 \%$ \\
\hline & Total & $100 \%$ & $100 \%$ \\
\hline \multicolumn{4}{|c|}{ Income level } \\
\hline & Below GHS 100 & $17 \cdot 3 \%$ & $24.9 \%$ \\
\hline & GHS 101-500 & $48.1 \%$ & $37.3 \%$ \\
\hline & GHS 501- 1000 & $23.6 \%$ & $25.8 \%$ \\
\hline & GHS 1001-2000 & $9.1 \%$ & $10.2 \%$ \\
\hline & Above 2000 & $1.9 \%$ & $1.8 \%$ \\
\hline & Total & $100 \%$ & $100 \%$ \\
\hline
\end{tabular}

Source: Survey results (2013)

4.2 The comparison of retailers' attributes that motivated people to shop is shown in Figure 2.

Figure 2: Respondents' motivation to shop at the retailer 
Survey results (2013).

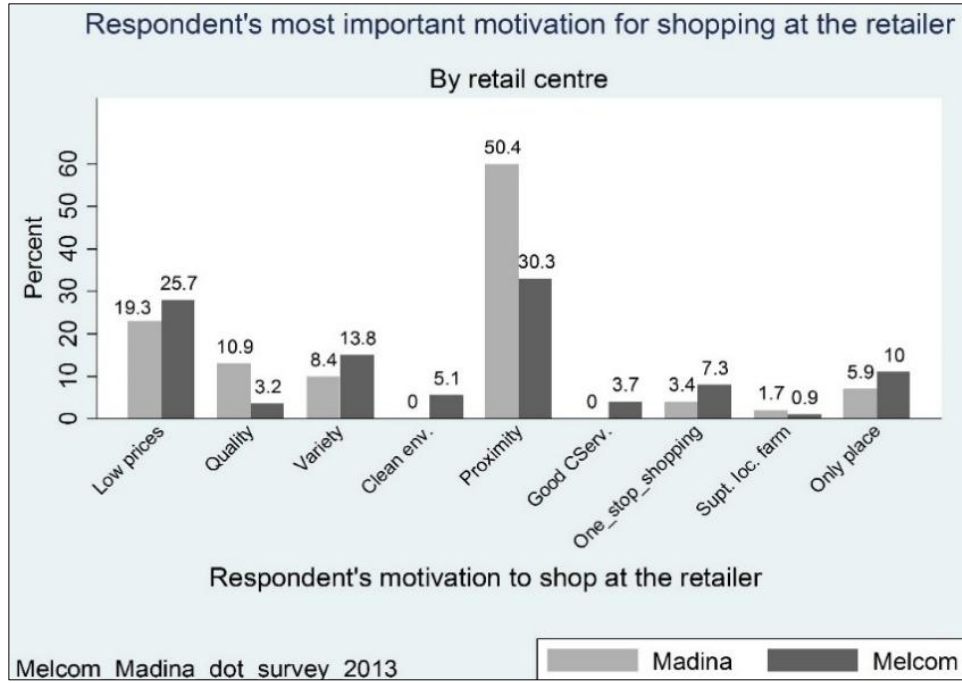

4.3 A comparison of the level of patronage of types of products at the wet-market and the supermarket is shown in Figure 3.

Figure 3: Types of products respondents bought at Madina market and Melcom supermarket

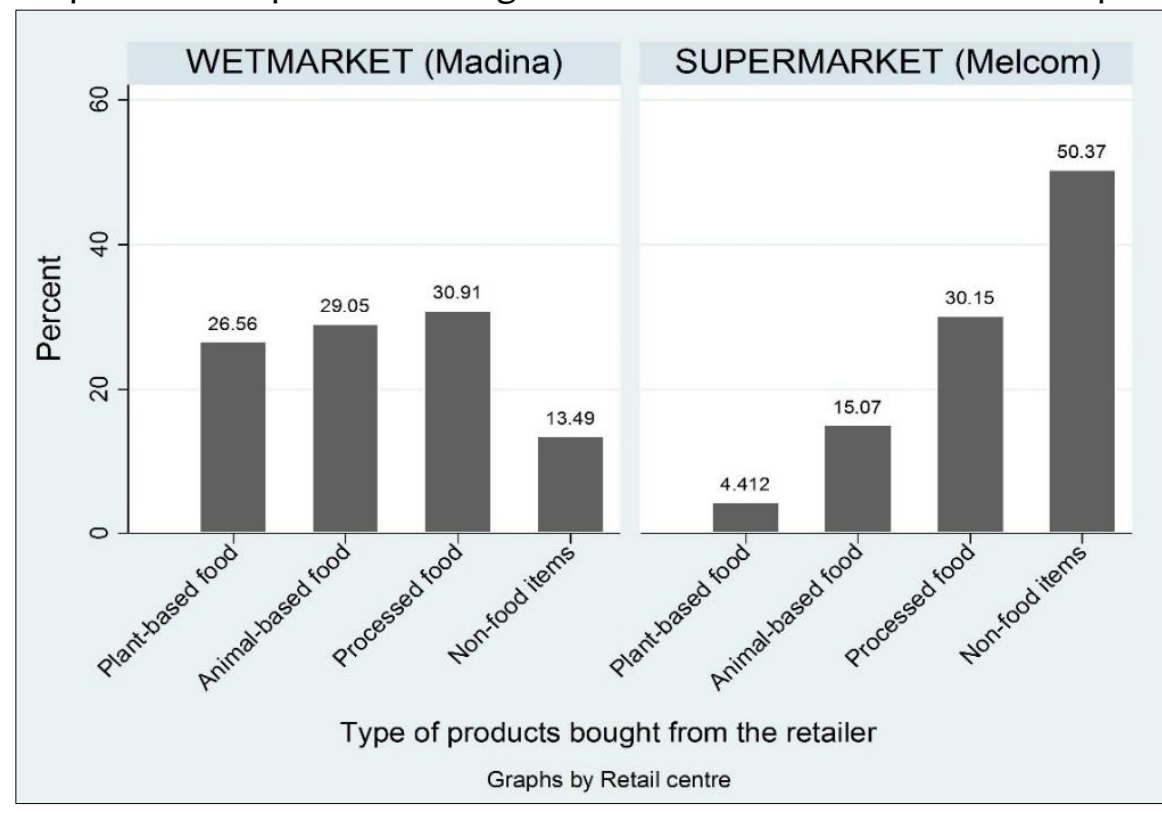

Survey results (2013).

\subsection{Factors to improve respondents' shopping experience}

Table 3: How the retailer can improve the respondents' shopping experience

\begin{tabular}{lrr} 
& & Retail Centre \\
\cline { 2 - 3 } Factors & Madina market & Melcom supermarket \\
\hline More car parking space & $28 \%$ & $35.4 \%$ \\
Making market less crowded & $21.5 \%$ & $6.2 \%$ \\
Toilets need upgrade & $16.9 \%$ & $23.4 \%$ \\
Need lighting and cold storage & $1 \%$ & $0 \%$ \\
Environment is dirty and needs cleaning & $25.8 \%$ & $2 \%$ \\
More product variety & $1.25 \%$ & $11 \%$ \\
Extended hours & $4.3 \%$ & $22 \%$ \\
Use of universal measurements & $1.25 \%$ & $0 \%$ \\
\hline
\end{tabular}

Source: Survey results (2013) 
1.5 The WMW test results on demographic and retailer attributes are summarised in Table 4 below.

Table 4: Summary results of the WMW test

\begin{tabular}{|c|c|c|c|c|}
\hline \multirow{2}{*}{ Variable } & & \multicolumn{3}{|c|}{ WMW test } \\
\hline & & z-statistic & P-value & $\mathrm{N}$ \\
\hline \multicolumn{5}{|c|}{ Demographic information } \\
\hline & Education & $-2.673^{* \star *}$ & 0.0053 & 438 \\
\hline & Income & 0.456 & 0.6487 & 433 \\
\hline & Age & $2.666^{* * *}$ & 0.0077 & 437 \\
\hline & Gender & $5.112^{* * *}$ & 0.000 & 765 \\
\hline & Residence & -0.969 & 0.3326 & 436 \\
\hline & Means of Transport & -1.074 & 0.2827 & 438 \\
\hline \multicolumn{5}{|c|}{ Retailer attributes } \\
\hline & Pricing & -0.019 & 0.0683 & 434 \\
\hline & Quality & $-1.823^{*}$ & 0.0683 & 435 \\
\hline & Variety & -0.515 & 0.6063 & 433 \\
\hline & Clean environment & $-9.767^{* * *}$ & 0.000 & 421 \\
\hline & Proximity & $6.994^{* * *}$ & 0.000 & 455 \\
\hline & Customer service & $-4.488^{* * *}$ & 0.000 & 425 \\
\hline & One-stop-shopping & $5.000^{* * *}$ & 0.000 & 425 \\
\hline & Only place & -0.321 & 0.7484 & 436 \\
\hline & Products & $-11.90 * * *$ & 0.000 & 754 \\
\hline
\end{tabular}

\section{DISCUSSIONS}

5.1 Socio-economic and demographic profile

The high representation of the local people (92\% of respondents at the Madina market and $94 \%$ of respondents at Melcom) was anticipated and is due to the fact that both retailers are community markets (350m apart) that serve the La-Nkwantanang-Madina Municipality. This illustrates the important role proximity plays when consumers decide to go shopping (Figure 2). This is consistent with findings of Ragland et al. (2011), where it was reported that $77.5 \%$ of surveyed respondents were Government employees whose offices were located within a five-block radius of the United States Department of Agriculture (USDA) farmers market. It further buttresses the fact that location of the retailer influences the consumer's choice of retail shop (Hawkins et al., 2004; Mendes and Themildo, 2004; Desai and Talukdar, 2003; McGoldrick, 2002) and also explains why a consumer would switch one retailer for another (Ghosh et al., 2010). The results of the socio-economic and demographic variables revealed that majority of the respondents at the supermarket (51.6\%) had tertiary education (degree, HND, diploma) compared to $37.6 \%$ of those at the wet-market. Of the patrons at the Supermarket, only $12 \%$ earn monthly incomes of GHS 1000 and above, with a similar trend (11\%) recorded at the wet-market. About $41 \%$ of those who visited the supermarket used their private cars while $26 \%$ of those who visited the wet-market went with their private cars. It is not surprising therefore that majority ( $28 \%$ at Madina and $35.4 \%$ at Melcom) of respondents at both retailers asked for the creation of more car parking space as a way of improving their shopping experience (Table 3). Similarly, the youth (aged 25-45yrs) make up the majority of respondents at both the supermarket (50\%) and wet-market (62\%). The WMW test results in Table 4 revealed a significant difference between consumers at the supermarket and the wet-market with regards to education level, gender and age group of respondents. However, there was no significant difference with regards to income level, means of transport to the retailer and place of residence. This suggests that irrespective of a consumer's income level and place of residence, they all visit both retailers for their choice of products. This result contradicts findings of Minten et al. (2010), Goldman and Hino 
(2005) and Hu et al. (2004) which suggest that a consumer with a high socio-economic status would prefer to shop at the supermarket. This is an indication that both the supermarket and the wet-market are selling to the same consumer segment in urban and peri-urban centres, unlike in the early days of supermarket diffusion where only the rich and affluent consumers in rich cities were privileged to buy from the supermarkets (as used to be the case of Europe, America and other developing countries in the first three waves of the supermarket diffusion in Table 1) (Asfaw, 2008; Hu et al., 2004). It is further revealing that the youth are driving the growth in the retail sector within the country and this concurs with findings of Ghosh et al. (2010) in their study carried out in India.

\subsection{Types of products sold}

The type of products bought from the retail centres were categorised as "Non-food" (including all items that are not edible), "Processed food" (comprising of staples such as rice, maize; flour or whole wheat bread; packaged foods such as pasta, sugar, edible oil, coffee, tea, cocoa drinks; beverages such as sodas, beer, wine, evaporated and condensed milk; condiments; and confectioneries), "Animal based food" (such as fresh fish, meat, and eggs) and "Plant based food" (such as fruits and vegetables). The survey results indicate from Figure 3 that the types of products bought from the wet-market differ greatly from that bought from the supermarket. This result is also validated by the test of significance where the types of products sold by both retailers were statistically significantly different from each other (Table 4). Consumers who visited the supermarket purchased non-food items more than food items. Figure 3 above shows that while $55.6 \%$ of respondents at the wet-market purchased fresh food products, less than $20 \%$ of those who visited the supermarket purchased fresh food items (Figure 3 ). Similarly, more than half $(50.37 \%)$ of responses at the supermarket purchased non-food products. This is consistent with findings of a research carried out in Indonesia by Nielsen (2007) in Reardon and Gulati (2008b), which revealed that consumers purchased fresh produce from the wet-markets because of cultural habits, low prices, credits and other personal services. This consistency is also reported in the work of Goldman and Hino (2005) where 95\% of respondents purchased perishable food items from traditional retailers. This gives an indication that the wet-markets still control the fresh food segment of the retail sector in Ghana while the supermarkets are carving a niche in the sale of processed foods and non-food products.

\subsection{The main reasons for store choice}

Respondents shop at both retailers because of Proximity, and Low prices, however, those at the Madina market shop there particularly because of Quality while those at the supermarket shop there because of Variety (Figure 2). The "quality-variety" difference was not validated by the statistical test of significance.

According to the results of table 4, there is no significant statistical difference between the respondents at both retailers with regards to the attributes of quality and variety. The perception of respondents is that both retailers sell good quality products with lots of variety at low prices and is close to them at their homes or work place. Their choice of retailer is obviously affected by these attributes which concurs with findings of several studies into the drivers of store preference by consumers which revealed that price, quality and variety affect consumer purchasing behaviours (Andreti et al., 2013; Chamhuri and Batt, 2013; Lakshmi et al., 2013; Prashar, 2013; Degeratu et al., 2000).

For instance, D'Haese and van Huylenbroeck (2005) reported that in South Africa, consumers preferred to buy their processed food (including fresh meat) from supermarkets because it is cheaper than from the local village shop. This trend is also reported in Botswana in the findings of Emongor (2008), where consumers bought cheaper processed products including fresh fruits and vegetables (FFV) from the supermarkets.

Results from table 4 further indicate a significant statistical difference between consumers at the supermarket and those at the wet-market with regards to attributes of clean environment, good customer service and offer of a one-stop-shopping experience. This result is consistent with findings of Jain and Bagdare (2009) where consumers in India affirm their preference for a particular retailer because of the attributes of clean environment, and one-stop-shopping experience. These attributes of clean environment, good customer service and offer of a one-stop-shopping experience have been discussed in 
findings of Ghosh et al. (2010) and Reardon and Hopkins (2006) and were categorised as Convenience shopping criterion. The Convenience of shopping is a very important shopping criterion that affects a consumer's purchasing decision. Whereas the patrons at the supermarket considered convenience as an influencer of their purchasing decision making, the results show that those respondents at the wetmarket were not so much concerned about convenience.

According to findings of earlier studies, consumers select a store based on location, convenience and merchandise mix (variety) and Services (including efficient billing system and prompt staff) (Ghosh et al., 2010). However, this study reveals that respondents in the wet-market purchase different products from those in the Supermarket. These findings suggest that respondents visit the supermarket for Convenience whiles those who visit the wet-market do so for freshness of produce which are complementary. It was revealed also that the social class of a respondent did not influence their choice of store. The economic implication of these findings is that, there is a market spill-over effect from the wet-market to the supermarket and vice-versa due to the complementary nature of services provided. This market spill-over effect also draws revenue to other shops located within the vicinity of both retail markets.

\section{Conclusion}

The activities of modern supermarkets in Ghana started around the early 1990 s with the opening of Melcom in Accra. The diffusion of supermarkets was slow at the onset, but by the mid-2000s onward, the development of the retail infrastructure coupled with the good political, economic, and judicial regime in the country attracted both local and international retail giants and expanded the modern retail outlets. The study investigated the existence of conflict between supermarkets and their traditional counterparts by exploring the consumer shopping behaviours of respondents in urban Accra (Madina) using data that was elicited for the purpose. The selection of both retail outlets was based on purposive sampling procedures while the selection of respondents was based on convenience sampling method (thus, those who were present at the retail centres and were willing to play the dot-game participated in the survey). In this study, we prove the theory that supermarket diffusion takes place across consumer segments (geographic and socio-economic) and across product categories. We illustrated that respondents at the supermarket came from the same socio-economic status with similar income level and geographical location but with different educational background. The highly educated preferred to shop at the supermarket instead of the wet-market. More than $50 \%$ of the respondents preferred to buy non-food items at the supermarket, fresh food items from the wet-market and processed food from either retail format. Each retailer receives its fair share of purchases from its loyal customers, therefore the revolution arising from the supermarket influx in Ghana has not yet resulted into conflict between supermarkets and their traditional counterparts, though it is inevitable if nothing is done to prevent it from happening.

\section{Policy recommendations}

i. The Municipal Authorities in-charge of traditional markets should institute policies that will enhance the competitiveness of the traditional market retailers by improving traditional market infrastructure, and also make the shopping environment clean and safe.

ii. Policies should be instituted to enable the traditional retailers position themselves on the Monopolistic fringe and co-exist with Modern retailers by carving a niche market such as in the sale of organic Fresh Fruits and Vegetables (FFV) and other local staples which are limited in the supermarkets.

iii. Government should institute policies that will give tax concession to modern retailers who source appreciable proportion of products from the local small-scale processors in the country. This would initiate partnerships between the modern retailers and lots of local processors thereby facilitating the upgrading of their technologies to meet market demand.

iv. Government parastatals like the Ghana Standards Authority and the Food and Drugs Authority should enforce public standards with regards to food safety laws in the traditional markets. This will boost consumer confidence in the safety of food products bought from the traditional market and maintain customer niche. 


\section{References}

Andersson, C. I., Chege, C. G., Rao, E. J., and Qaim, M. (2015). Following up on smallholder farmers and supermarkets in Kenya. American Journal of Agricultural Economics, 97(4): 1247-1266. Doi: 10.1093/ajae/aavoo6

Andreti, J., Zhafira, N. H., Akmal, S. S., and Kumar, S. (2013). The analysis of product, price, place, promotion and service quality on customers' buying decision of Convenience Store: A survey of young adult in Bekasi, West Java, Indonesia. International Journal of Advances in Management and Economics, 2 (6): $72-78$.

Asfaw, A. (2008). Does supermarket purchase affect the dietary practices of households? Some empirical evidence from Guatemala. Development Policy Review, 26 (2): 227-243.

Assefa, T., Abebe, G., Lamoot, I., and Minten, B. (2016). Urban food retailing and food prices in Africa: the case of Addis Ababa, Ethiopia. Journal of Agribusiness in Developing and Emerging Economies, 6(2): 90-109. Doi: 10.1108/JADEE-02-2015-0009

Battersby, J., and Peyton, S. (2014). The geography of supermarkets in Cape Town: Supermarket expansion and food access. Urban Forum, 25 (2): 153-164. Doi: 10.1007/s12132-014-9217-5

BBC News India. (2012). India strike over supermarket reforms. The BBC, http://www.bbc.co.uk/news/world-asia-india-19658146 [accessed: 1 December 2013]

Biles, J. (2006). Globalization of food retailing and the consequences of Wal-Martization in Mexico. In S. D. Brunn (ed.). Wal-Mart World: The World's Biggest Corporation in the Global Economy. pp. 343-355. New York: Taylor \& Francis.

Biles, J. J., Brehm, K., Enrico, A., Kiendl, C., Morgan, E., Teachout, A., and Vasquez, K. (2007). Globalization of food retailing and transformation of supply networks: consequences for small-scale agricultural producers in Southeastern Mexico. Journal of Latin American Geography. 6(2): 55-75.

Chamhuri, N., and Batt, P. J. (2013). Exploring the factors influencing consumers' choice of retail store when purchasing fresh meat in Malaysia. International Food and Agribusiness Management Review, 16 (3): $99-122$.

Coe, N. M., and Wrigley, N. (2007). Host economy impacts of transnational retail: the research agenda. Journal of Economic Geography, 7:341-371. doi:10.1093/jeg/lbmo12

Crush, J., and Frayne, B. (2011). Supermarket expansion and the informal food economy in Southern African cities: implications for urban food security. Journal of Southern African Studies. 37(4): 781807.

Degeratu, A.M., Rangaswamy, A., and Wu, J. (2000). Consumer choice behaviour in online and traditional supermarkets: The effects of brand name, price and other search attributes. Intern. J. of Research in Marketing, 17: 55-78

Desai, K. and Talukdar, D. (2003). Relationship between category price perceptions, shopper's basket size, and overall store price image: An analysis of the grocery market . Psychology \& Marketing, 20 (10): $903-933$.

D'Haese, M., and Van Huylenbroeck, G. (2005). The rise of supermarkets and changing expenditure patterns of poor rural households case study in the Transkei area, South Africa. Food Policy, 30 (1), 97-113.

Duedu, K. O., Yarnie, E. A., Tetteh-Quarcoo, P. B., Attah, S. K., Donkor, E. S., and Ayeh-Kumi, P. F. (2014). A comparative survey of the prevalence of human parasites found in fresh vegetables sold in supermarkets and open-aired markets in Accra, Ghana. BMC research notes, 7(1): 836.

Emongor, R.A. (2008). The impact of South African supermarkets on agricultural and industrial development in the Southern African Development Community. Ph.D. Dissertation, University of Pretoria, South Africa.

Faiguenbaum, S., Berdegué, J. A., and Reardon, T. (2002). The rapid rise of supermarkets in Chile: effects on dairy, vegetable, and beef chains. Development Policy Review, 20 (4): 459-471.

Ghana Statistical Service. (2012). 2010 Population and housing census: summary report of final results. Pp.118. Accra: Ghana Statistical Service.

Ghosh, P., Tripathi, V., and Kumar, A. (2010). Customer expectations of store attributes: A study of organised retail outlets in India. Journal of Retail \& Leisure Property, 9 (1): 75-87. 
Goldman, A., and Hino, H. (2005). Supermarkets vs. traditional retail stores: diagnosing the barriers to supermarkets' market share growth in an ethnic minority community. Journal of Retailing and Consumer Services 12(4): 273-284.

Hamilton, B. A. (2003). Creating Value in Retailing for Emerging Consumers Breaking the Myths about Emerging Consumers-Learning from Small Scale Retailers. An Exploratory Study conducted for the Coca-Cola Retail Research Center-Latin America. Pp.32

Hawkins, D.I., Best, R.J. and Coney, K.A. (2004) Consumer behavior: building marketing strategy, 9th edn. New York: McGraw-Hill.

Hawthorne Valley Farm. 2010. Farmers' market study 2010. In: The 9 farmers' markets of Columbia county. Hu, D., Reardon, T., Rozelle, S., Timmer, P., and Wang, H. (2004). The emergence of supermarkets with Chinese characteristics: challenges and opportunities for China's agricultural development. Development Policy Review, 22 (5): 557-586.

Humphrey, J. (2007). The supermarket revolution in developing countries: tidal wave or tough competitive struggle? Journal of Economic Geography, 7: 433-450. doi: 10.1093/jeg/lbmoo8

Jain, R. and Bagdare, S. (2009). Determinants of customer experience in new format retail stores. Journal of Marketing \& Communiciation, 5 (2): 34-44

Lakshmi, N.K. Ajata, S.S. and Nagara, P.R. (2013). A study on consumer buying behaviour towards organised and unorganised retail stores in Bangalore City. International Journal of Management Research and Business Strategy, 2 (3): 35-46.

Lev, L., Stephenson, G., and Brewer L. (2007). Practical research methods to enhance farmers markets. In C.C. Hinrichs and T.A. Lyson, (Eds.). Remaking the North American food system: strategies for sustainability. Pp 84-98. University of Nebraska Press.

Lev, L., Brewer, L.J., and Stephenson, G.O. (2008). Tools for rapid market assessments. Technical Report, Number 6: 26. United States.

Lomotey, D. (2013). Madina market women defiant about moving from road side. E.tv Ghana, http://www.etvghana.com/index.php?option=com_content\&view=article\&id=3226:madina-marketwomen-defiant-about-moving-from-road-side $\&$ catid=120\&Itemid=530 [accessed: 1 September 2013]

Mabogunje, A. L. (1964). The evolution and analysis of the retail structure of Lagos, Nigeria. Economic Geography, 40(4): 304-323.

McGoldrick, P. (2002). Retail marketing, 2nd edn. Pp. 658. London: McGraw-Hill .

McTaggart, D., Findlay, C., and Parkin, M. (2010). Economics. $6^{\text {th }}$ ed. Pp. 714. Australia: Pearson.

Melcom Group. (2010a). Welcome to Melcom group of companies. Melcom Group, http://www.melcomgroup.com/index_2.html [accessed: 23 November 2013]

_. (2010b). Melcom stores. Melcom Group, http://www.melcomgroup.com/melcom_stores.html\# [accessed: 23 November 2013]

2. (2010c). About Melcom Itd. Melcom Group Ltd, http://melcom.essindia.net/index.php?option=com_content\&view=article\&id=43\&ltemid=108 [accessed: 23 November 2013]

Mendes, A. and Themido, I. (2004). Multi outlet retail site location assessment . International Transactions in Operational Research. 11 (1): 1 - 18.

Meng, T., Florkowski, W. J., Sarpong, D. B., Chinnan, M. S., and Resurreccion, A. V. (2014a). Consumer's food shopping choice in Ghana: Supermarket or Traditional Outlets?. International Food and Agribusiness Management Review. 17 (Special Issue A): 107-130

- (2014b). Modeling food retail format choice and shopping frequency decision in urban Ghana: a multivariate ordered probit regression application. Paper prepare for presentation at the Annual Meeting of the Agricultural and Applied Economics Association, Minneapolis, July 27-29.

Ministry of Local Government \& Rural Development. (2013). Metropolitan, Municipal and District Assemblies in Ghana. In MMDA's chart. Homepage: Ministry of Local Government \& Rural Development (MLGRD), http://www.mlgrdghanagov.com/default/index.php/mmda-s-chart [accessed: 10 September 2013].

Minten, B. (2008). The food retail revolution in poor countries: Is it coming or is it over?. Economic Development and Cultural Change. 56(4): 767-789. 
Minten, B., Randrianarison, L., and Swinnen, J. F. (2005). Supermarkets, international trade and farmers in developing countries: Evidence from Madagascar. Cornell Food and Nutrition Policy Program Working Paper No. 191. Pp. 36. Doi: 10.2139/ssrn.848486

Minten, B., Reardon, T., and Sutradhar, R. (2010). Food prices and modern retail: The case of Delhi. World Development, 38 (12): 1775-1787.

MOFA. (2013). Ga East Municipal. Ministry of Food \& Agriculture (MOFA), Republic of Ghana, http://mofa.gov.gh/site/?page_id=1571 [accessed: 1 September 2013]

Neven, D., Odera, M. M., Reardon, T., and Wang, H. (2009). Kenyan supermarkets, emerging middle-class horticultural farmers, and employment impacts on the rural poor. World Development, 37(11): 18021811.

Neven, D., and Reardon, T. (2004). The rise of Kenyan supermarkets and the evolution of their horticulture product procurement systems. Development Policy Review. 22(6): 669-699.

Neven, D., Reardon, T., Chege, J., and Wang, H. (2006). Supermarkets and consumers in Africa: the case of Nairobi, Kenya. Journal of International Food \& Agribusiness Marketing, 18 (1-2): 103-123.

Peyton, S., Moseley, W., and Battersby, J. (2015). Implications of supermarket expansion on urban food security in Cape Town, South Africa. African Geographical Review, 34(1): 36-54. Doi: 10.1080/19376812.2014.1003307

Prashar, A. (2013). Drivers of store choice in an evolving market: an empirical study. International Journal of Advancements in Research \& Technology, 2 (8): 195-202.

Qaim, M., Andersson, C. I., Chege, C. G., Kimenju, S. C., Klasen, S., and Rischke, R. (2014). Nutrition effects of the supermarket revolution on urban consumers and smallholder farmers in Kenya. GlobalFood Discussion Papers, No. 40. Pp27

Ragland, E., Lakins, V., and Carlos, C. (2011). Results of dot survey: USDA outdoor farmers market, Washington, DC. Pp. 26. US Department of Agriculture, Agriclutural and Marketing Service, http://dx.doi.org/10.9752/MS043.09-2011 [accessed: 15 January 2013]

Rao, E. J., and Qaim, M. (2011). Supermarkets, farm household income, and poverty: insights from Kenya. World Development, 39(5): 784-796.

Reardon, T. (2011). The global rise and impact of supermarkets: an international perspective. A paper presented at a conference on the theme: "The supermarket revolution in Food: good, bad or ugly for the world's farmers, consumers and retailers?" Conference conducted by the Crawford Fund for International Agricultural Research, Parliament House, Canberra, Australia, 14-16 August.

Reardon, T., Berdegue, J. A., and Timmer, C. P. (2005). Supermarketization of the emerging markets of the Pacific Rim: development and trade implications. Journal of Food Distribution Research, 36(1), 312.

Reardon, T., and Hopkins, R. (2006). The supermarket revolution in developing countries: policies to address emerging tensions among supermarkets, suppliers and traditional retailers. The European journal of development research 18(4): 522-545.

Reardon, T., and Gulati, A. (2008a). The supermarket revolution in developing countries: policies for “competitiveness with inclusiveness". International Food Policy Research Institute, Policy Brief 2: 1-2.

- (2008b). The rise of supermarkets and their development implications, International experience relevant for India. IFPRI Discussion Paper 00752, February 2008.

Reardon, T., Henson, S., and Berdegué, J. (2007). 'Proactive fast-tracking' diffusion of supermarkets in developing countries: implications for market institutions and trade. Journal of Economic Geography, 7 (4): 399-431.

Reardon T, Henson S, and Gulati A. (2010). Links between supermarkets and food prices, diet diversity and food safety in developing countries. In C. Hawkes, C. Blouin, S. Henson, N. Drager, and L. Dubé (Eds.). Trade, Food, Diet and Health: Perspectives and Policy Options. Pp.111-130. Hoboken, NJ: WileyBlackwell.

Reardon, T., Timmer, C.P. Barrett, C.B. and Berdegué, J. (2003). The rise of supermarkets in Africa, Asia, and Latin America. American journal of agricultural economics, 85 (5): 1140-1146.

Reardon, T., Timmer, C. P., and Berdegue, J. A. (2004). The rapid rise of supermarkets in developing countries: induced organizational, institutional, and technological change in agrifood systems. electronic Journal of Agricultural and Development Economics. 1(2):168-183. 
Reuters. (2011). FDI in retail: Indian traders protest against the entry of retail giants. International Business Times, http://www.ibtimes.com/fdi-retail-indian-traders-protest-against-entry-retail-giants377042 [accessed: 1 December 2013]

Rodríguez, E., Berges, M., Casellas, K., Paola, R. D., Lupín, B., Garrido, L., and Gentile, N. (2002). Consumer behaviour and supermarkets in Argentina. Development Policy Review, 20(4): 429-439.

Suryadarma, D. (2011). Competition between traditional food traders and supermarkets in Indonesia. A paper prepared for presentation at The supermarket revolution in Food: good, bad or ugly for the world's farmers, consumers and retailers?. Conference conducted by the Crawford Fund for International Agricultural Research, Parliament House, Canberra, Australia, 14-16 August.

Tessier, S., Traissac, P., Bricas, N., Maire, B., Eymard-Duvernay, S., El Ati, J., and Delpeuch, F. (2010). Food shopping transition: socio-economic characteristics and motivations associated with use of supermarkets in a North African urban environment. Public health nutrition. 13(09): 1410-1418.

Timmer, C. P. (2009). Do supermarkets change the food policy agenda?. World Development. 37(11): 18121819.

Timmer, P. (2004). Food policy in the era of supermarkets: what's different. Electron J Agric Environ Econ, 1: $50-67$.

UNCTAD. (2003). Investment policy review: Ghana [in English]. UNCTAD/ITE/IPC/Misc.14/Rev.1. Pp. 103. Switzerland: United Nations.

van Wijk, M. S., Cuong, T. H., Tru, N. A., and Van Hoi, P. (2005). Opportunities for farmers: 'Safe' vegetables for Hanoi. LEISA: ILEIA newsletter for low-external-input and sustainable agriculture. 21(2): 28-29.

Weatherspoon, D. D., and Reardon, T. (2003). The rise of supermarkets in Africa: implications for agrifood systems and the rural poor. Development policy review, 21(3): 333-355.

World Bank Group. (2007). Snapshot Africa-Ghana: Benchmarking FDI competitiveness. Pp. 66. USA: MIGA. 